\title{
Antioxidant capacity is correlated with steroidogenic status of the corpus luteum during the bovine estrous cycle
}

\author{
Revital Rapoport a,b, David Sklan a , David Wolfenson a , Amira Shaham-Albalancy a, \\ Israel Hanukoglu b,* \\ a The Faculty of Agriculture, Hebrew University, Rehovot 76100, Israel \\ ${ }^{\mathrm{b}}$ E. Katzir Biotechnology Program, The Research Institute, College of Judea and Samaria, Ariel 44837, Israel
}

Received 1 July 1997; revised 8 October 1997; accepted 9 October 1997

\begin{abstract}
The reactions of steroid hormone biosynthesis are accompanied by formation of oxygen radicals. We determined the levels of some antioxidants and antioxidative enzymes at different developmental stages of bovine corpora lutea to examine their correlation with steroidogenic status. Plasma progesterone concentrations of estrous cycle synchronized cows increased until day 16, and then decreased rapidly during luteal regression. The levels of steroidogenic cytochrome $P 450$ scc and adrenodoxin paralleled the changes in plasma progesterone. Among the antioxidative enzymes examined, the SOD and catalase activities showed patterns most similar to plasma progesterone. Catalase and SOD activities increased 6-8 fold from day 6 to 16 of the estrous cycle and then decreased during the luteal regression. Ascorbate and $\beta$-carotene showed low but significant correlation with $P 450 \mathrm{scc}$ and plasma progesterone levels. The profiles of two lipophilic antioxidants in corpora lutea were very different. $\beta$-carotene concentration increased by approximately 6 fold from day 6 to 16 , and decreased in regressive tissue. $\alpha$-tocopherol showed a 3 fold increase between days 6 and 9 followed by a rapid decrease. Thus, at the peak of steroidogenesis at mid-luteal phase $\alpha$-tocopherol levels decreased, but $\beta$-carotene levels increased. The correlation between the levels of some antioxidant enzymes and compounds with progesterone levels indicates that antioxidative mechanisms are activated to cope with steroidogenesis dependent oxyradical formation in the bovine corpus luteum. (C) 1998 Elsevier Science B.V.
\end{abstract}

Keywords: Ascorbic acid; $\beta$-Carotene; Catalase; Cholesterol; Cytochrome P450scc; Superoxide dismutase; $\alpha$-Tocopherol

\section{Introduction}

Most of the steps in the biosynthesis of steroid hormones are catalyzed by cytochrome $P 450$ type enzymes located in the mitochondria and endoplasmic reticulum. These reactions are dependent on the

\footnotetext{
* Corresponding author. Fax: 972-3-9640956; E-mail: israel@research.yosh.ac.Il
}

transfer of electrons from NADPH to $P 450$ via electron transfer proteins adrenodoxin reductase and adrenodoxin in the mitochondria, and cytochrome $P 450$ reductase in the endoplasmic reticulum $[1,2]$. In reconstituted enzyme systems, a significant portion of electrons may "leak" to other acceptors, such as $\mathrm{O}_{2}$, and generate harmful oxy-radicals [3-5]. The degree of coupling of electron transfer to substrate hydroxylation varies among different $P 450$ systems [3-5]. During steroidogenesis, the mitochondrial $P 450$ sys- 
tems have been shown to produce oxygen radicals that may cause irreversible damage to molecules in the immediate surroundings such as cytochrome $P 450$ and adrenodoxin [4-6].

The mitochondrial $P 450$ scc system that catalyzes the first and the rate limiting step in steroidogenesis is expressed in highest concentrations in the adrenal cortex and the ovarian corpus luteum [7]. These steroidogenic tissues also contain high levels of antioxidants such as ascorbate, $\alpha$-tocopherol, $\beta$-carotene and the enzymes superoxide dismutase (SOD), catalase, glutathione peroxidase, glutathione- $S$-transferase and glutathione reductase [8-12]. One function of these antioxidants may be protection against oxygen radicals produced during steroidogenesis $[8,12]$. Yet, oxygen radicals may also be functional in leading to luteolysis and apoptosis in corpus luteum during each reproductive cycle [12-14].

As the steroidogenic capacity of the corpus luteum shows major changes during the estrous cycle [7,15], we wished to determine whether protective mechanisms against oxidative damage are correlated with progesterone production in bovine corpus luteum at different stages of development. For this purpose we examined the levels of progesterone, P450scc, and selected antioxidants throughout the estrous cycle in the bovine corpora lutea.

\section{Materials and methods}

\subsection{Synchronization of cows}

The estrous cycle of Israeli-Holstein dairy cows $(n=36)$ from commercial herds was synchronized by intra-muscular injection of $625 \mu \mathrm{g}$ Cloprostenal (prostaglandin $\mathrm{F}_{2 \alpha}$ analog, Estrumate, Coopers, Burgwedel, Germany). Cows that manifested behavioral estrus (day 0) within 4 days following the injection were slaughtered and their ovaries were collected on ice on days $6,9,13$, and 16 of the cycle. In addition, regressive corpora lutea were collected from 10 cows (not injected with $\mathrm{PGF}_{2 \alpha}$ ). These corpora lutea were characterized according to the criteria of Ireland et al. [16]. Corpora lutea were dissected from the surrounding tissue, processed immediately or stored at $-80^{\circ} \mathrm{C}$ until analysis.

\subsection{Assays}

For catalase and SOD assays, fresh (unfrozen) tissue was homogenized immediately in 1:11 (w/v) $50 \mathrm{mM} \mathrm{K}$ phosphate buffer, pH 7.4, $150 \mathrm{mM} \mathrm{KCl}$, and $200 \mu \mathrm{M}$ EDTA. Protein concentration in the homogenate was determined by the biuret assay using bovine serum albumin as a standard [17]. Protein concentration in the homogenates was $12-22 \mathrm{mg} / \mathrm{ml}$. The homogenate was centrifuged at $700 \times g$ for $20 \mathrm{~min}$ at $4^{\circ} \mathrm{C}$. A portion of the cytoplasmic supernatant obtained was stored frozen for later assay of SOD.

For catalase assay a 3-20 $\mu 1$ portion of the resulting supernatant was added to $700 \mu \mathrm{l}$ of $5 \mathrm{mM} \mathrm{H}_{2} \mathrm{O}_{2}$ solution in homogenization buffer kept at $37^{\circ} \mathrm{C}$ in a thermostated cuvette. The rate of decomposition of $\mathrm{H}_{2} \mathrm{O}_{2}$ was followed by determining the rate of decrease in absorbance at $240 \mathrm{~nm}\left(\epsilon 240 \mathrm{~nm}=43.5 \mathrm{M}^{-1}\right.$ $\left.\times \mathrm{cm}^{-1}\right)$, and the activity of catalase was calculated as described [18].

For SOD assay the frozen supernatant was thawed and processed as described [19]. SOD activity was measured using xanthine-xanthine oxidase system as a source of superoxide and nitroblue tetrazolium as a scavenger for this radical [20]. One unit of SOD activity was defined as the amount causing 50\% inhibition of the initial rate of reduction of NBT [21].

The levels of adrenodoxin, and $P 450 \mathrm{scc}$ were estimated by Western blot analysis [7,22-24]. The samples of purified proteins or homogenized tissue fractions ( $20 \mu \mathrm{g}$ protein) were dissolved in gel sample buffer (final concentration: $60 \mathrm{mM}$ Tris, $\mathrm{pH} 6.8$, $1 \%$ SDS, $10 \%$ glycerol, $10 \%$ 2-mercaptoethanol) and heated to $100^{\circ} \mathrm{C}$ for $2 \mathrm{~min}$ and electrophoresed on $8.5 \%$ or $15 \%$ (for adrenodoxin only) polyacrylamide gels with SDS. The blots were reacted with horseradish peroxidase linked-protein A followed by reaction with ECL-Western blotting kit (Amersham, England) (instead of reaction with ${ }^{125}$ I-protein A). The resulting chemiluminescence was detected by short exposure to autoradiography film. The intensities of the bands were measured by densitometry. On each gel, in addition to tissue homogenates, four concentrations of purified enzymes were run to establish a standard curve for estimation of protein level. Protein levels were estimated in triplicate in tissue homogenates at different developmental stages of 
corpus luteum on a dot-blot where $200 \mu \mathrm{l}$ of diluted homogenates (of $2 \mu \mathrm{g}$ protein content) were applied directly onto nitrocellulose paper using the same protocol for quantitation.

For measurement of lipids, 200-250 mg of thawed tissue was cut into thin slices and saponified with ethanolic $\mathrm{KOH}$ (freshly prepared by mixing 1:4 60\% $\mathrm{KOH}$ with ethanol) by gently shaking at $65^{\circ} \mathrm{C}$ for 60 min. Unsaponifiable materials were extracted into petroleum ether, concentrated to $1 \mathrm{ml}$ and stored at $-20^{\circ} \mathrm{C}$ for later determinations of cholesterol, progesterone, $\beta$-carotene and $\alpha$-tocopherol. Cholesterol was determined as described [25]. For tissue progesterone determination $100 \mu l$ of the organic phase was evaporated under nitrogen, dissolved in phosphate buffered saline, $\mathrm{pH} 7.5$, with $0.8 \%$ gelatin, $0.1 \%$ $\mathrm{NaN}_{3}$, for RIA [26]. The sensitivity of the assay was $7.8 \mathrm{pg} / \mathrm{vial}$, the intra- and interassay coefficient of variation were $8.6 \%$ and $4.6 \%$ respectively. Plasma progesterone was assayed by the same method.

The saponified fraction was acidified with $8 \mathrm{~N} \mathrm{HCl}$ and the fatty acids were extracted with petroleum ether. Total fatty acids were assayed gravimetrically [27].

For ascorbate assay about $200 \mathrm{mg}$ of tissue was homogenized in 60\% methanol [28]. The homogenate was centrifuged at $1000 \times g$ and the supernatant was filtered through a $0.45 \mu \mathrm{m}$ filter (Millipore). Ascorbate was determined by isocratic high-pressure liquid chromatography on an Econosil C-18 reversed phase column $(250 \times 4.6 \mathrm{~mm}$, Merck) eluted with $0.1 \%$ phosphoric acid, $\mathrm{pH} 3.0$, and methanol (50:50), at a flow rate of $0.3 \mathrm{ml} / \mathrm{min}$ [29]. Absorbance was recorded at $265 \mathrm{~nm}$.

For measurement of $\alpha$-tocopherol and $\beta$-carotene, $2 \mu \mathrm{g}$ of retinyl-acetate was added as an internal standard to an aliquot of the unsaponifiable fraction. The lipids were separated by isocratic high-pressure liquid chromatography on an Econosil C-18 reversed phase column $(250 \times 4.6 \mathrm{~mm}$, Merck $)$ eluted with methanol:ethyl-acetate $(70: 30)$, at a flow rate of $0.3 \mathrm{ml} / \mathrm{min}$ [30]. The fluorescent detector was programmed with excitation at $330 \mathrm{~nm}$ and emission at $470 \mathrm{~nm}$ from 0 to $7.5 \mathrm{~min}$ for retinyl acetate detection, and at excitation $290 \mathrm{~nm}$, and emission $330 \mathrm{~nm}$ from 7.5 to $25 \mathrm{~min}$ for $\alpha$-tocopherol detection. $\beta$ carotene was detected with the UV-VIS detector at $450 \mathrm{~nm}$.

Unless otherwise specified, the concentrations in all assays were expressed per wet weight of tissue.

\subsection{Statistical analysis}

Difference between treatments were examined by analysis of variance with two tailed $t$-tests between each pair of treatments using the SAS general linear model procedures (SAS 1986). Significance was $P<$ 0.05 unless otherwise noted. Results are the means \pm SE of 6 individual (unpooled) corpora lutea from 6 different cows per day. The value for each corpus
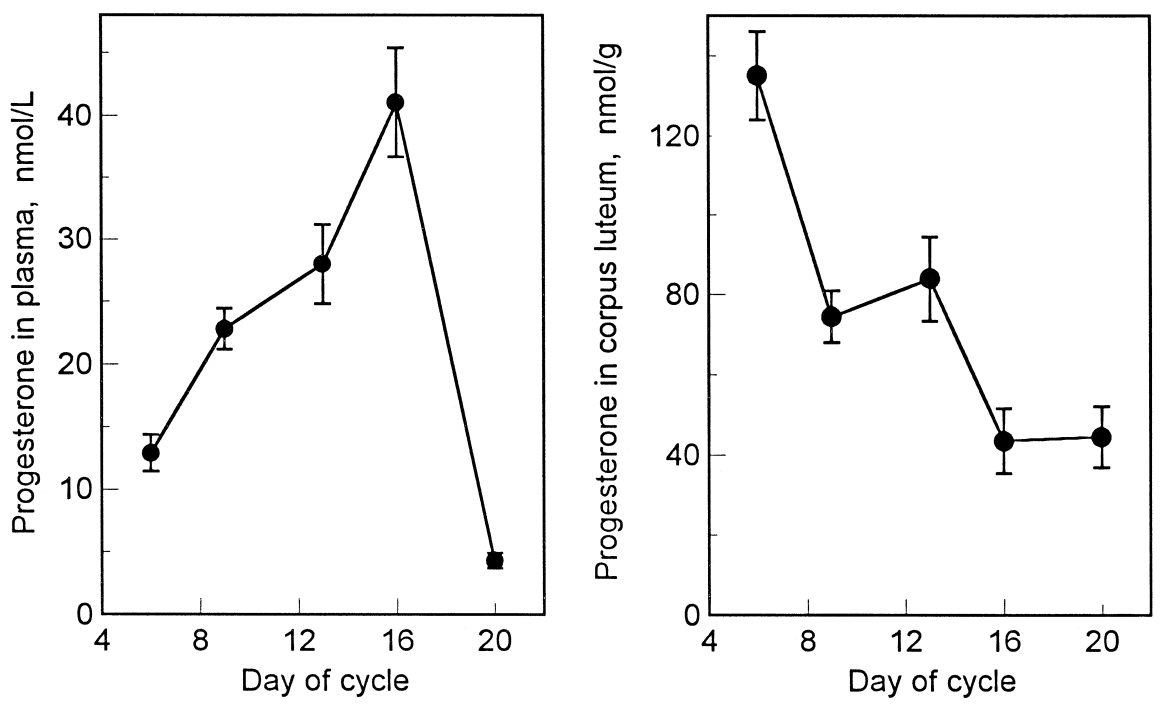

Fig. 1. Progesterone levels in plasma and in corpus luteum during the synchronized estrous cycles of cows. Day 0 is the day of estrus. 

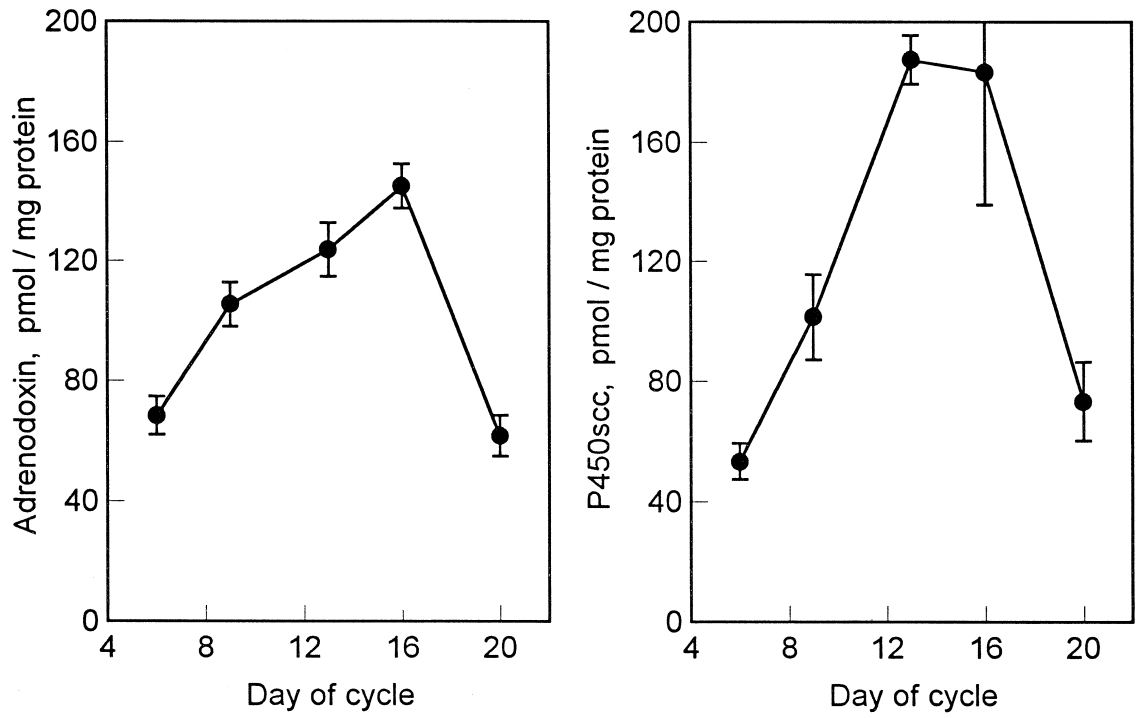

Fig. 2. Levels of adrenodoxin and P450scc in corpus luteum.

luteum was the average of three independent measurements.

\section{Results and discussion}

\subsection{Steroidogenic status}

The concentration of plasma progesterone showed a normal pattern according to the day of the estrous cycle [15,31], increasing until day 16 , and then decreasing rapidly during luteal regression (Fig. 1). The peak level of blood progesterone was associated with a decrease in luteal tissue level of progesterone (Fig. 1). The levels of both adrenodoxin and $P 450 \mathrm{scc}$ paralleled the changes in plasma progesterone (Fig. 2), showing correlation coefficients of 0.66 and 0.72 respectively (Table 1).

The tissue concentration of cholesterol increased during the early luteal phase and then decreased when progesterone levels in plasma were high. (Fig. 3 ). Since cholesterol is the precursor of ovarian steroids, its decrease may be a result of enhanced utilization by steroidogenesis. The changes in cholesterol levels were not accompanied by a change in the levels of the total lipids which showed a small but not significant tendency to increase until day 22 (Fig. $3)$.

\subsection{Correlation of antioxidant levels with steroido-} genesis

Among the antioxidants examined, the concentrations of SOD and catalase showed patterns similar to those of steroidogenic enzymes and plasma progesterone, peaking at day 16 and decreasing during the luteal phase (Fig. 4). Catalase and SOD activities increased 6-8 fold from day 6 to 16; catalase decreased to about $40 \%$ of the maximal value in regressive tissue and SOD to about $60 \%$. Both activities were significantly correlated with plasma progesterone (Table 1).

In the corpus luteum of pregnant rats and in pseudopregnant rabbits, SOD activity was also found to parallel plasma progesterone levels [32-34]. Overall

Table 1

Correlations between plasma progesterone, steroidogenic enzyme, and antioxidant levels in the bovine corpus luteum during estrous cycle. Only results with $P<0.1$ are shown

\begin{tabular}{llll}
\hline Dependent & Independent & $r$ & $P<$ \\
\hline Progesterone & $P 450$ scc & 0.72 & 0.09 \\
Progesterone & Adrenodoxin & 0.66 & 0.07 \\
Progesterone & Catalase & 0.50 & 0.001 \\
Progesterone & $\beta$-carotene & 0.43 & 0.09 \\
Progesterone & SOD & 0.66 & 0.001 \\
Ascorbate & $P 450$ scc & 0.56 & 0.05 \\
Catalase & Adrenodoxin & 0.42 & 0.10 \\
\hline
\end{tabular}



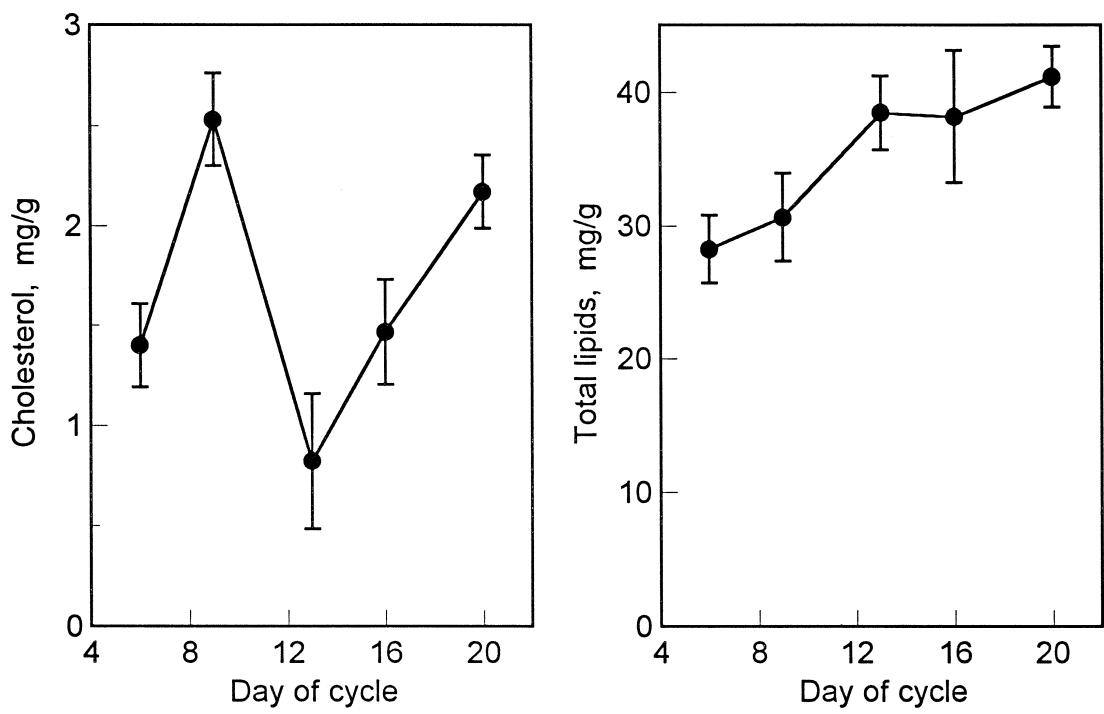

Fig. 3. Concentration of cholesterol and total lipids in corpus luteum.

these findings indicate that SOD activity is coregulated with steroidogenesis in the corpora lutea of animals with widely differing profiles of estrous cycles.

In the early part of the estrous cycle SOD is expected to play a protective antioxidant role. The superoxide producing xanthine oxidase system was demonstrated to inhibit progesterone synthesis in rat luteal cells [35] and to disrupt rat luteal cell membranes [36]. The high levels of catalase and SOD at day 16, when progesterone synthesis is maximal, most probably have a protective role against locally produced radicals.

In the luteolytic phase, the balance of the activities of the antioxidant enzymes may determine the dispensation of oxygen radical species. Thus, the smaller decrease in SOD activity relative to catalase (Fig. 4) may lead to an accumulation of $\mathrm{H}_{2} \mathrm{O}_{2}$ in tissue from rapid dismutation of superoxide radicals. Superoxide and/or $\mathrm{H}_{2} \mathrm{O}_{2}$ may be involved in the luteolytic process by mediating phospholipase $\mathrm{A}_{2}$ activation which is the rate-limiting enzyme in the synthesis of
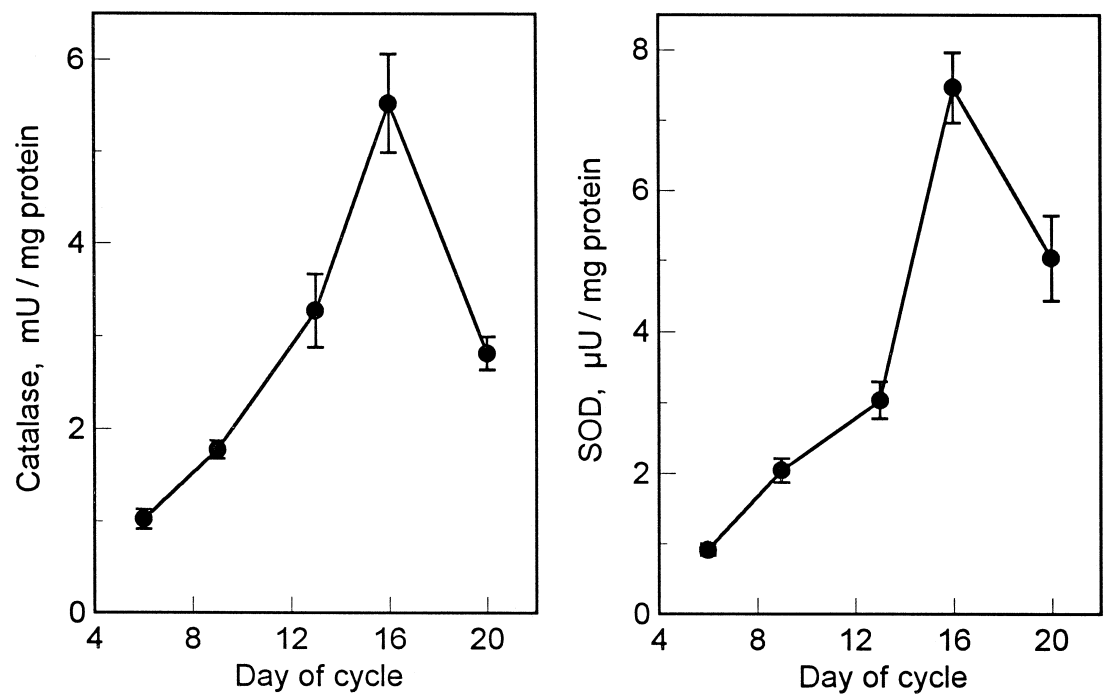

Fig. 4. Activities of antioxidant enzymes, catalase and SOD, in corpus luteum. 


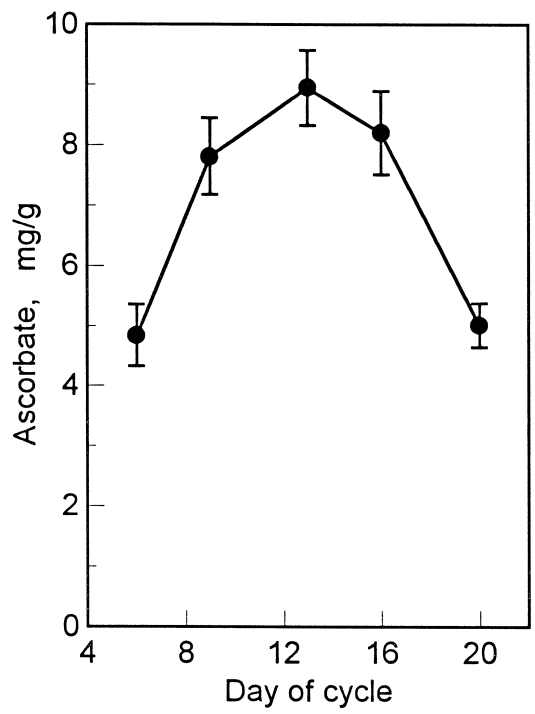

Fig. 5. Concentration of ascorbate in corpus luteum.

PGF $2 \alpha$ that acts as a luteolytic signal [13,35,37-39]. Catalase can reverse the luteolytic action of superoxide, supporting the idea that $\mathrm{H}_{2} \mathrm{O}_{2}$, and not superoxide, may have a dominant role in activating phospholipase $\mathrm{A}_{2}$ [37].

Examination of other antioxidant compounds revealed that ascorbate and $\beta$-carotene showed a low but significant correlation with parameters of steroidogenic status (Table 1). Ascorbate levels in tissue are much higher than those of $\beta$-carotene. Ascorbate levels increased nearly 2 fold and then decreased (Fig. 5). The profiles of the two lipophilic antioxidants studied were different (Fig. 6). $\beta$-Carotene concentration increased by approximately 6 fold from day 6 to 16, and decreased in regressive tissue. In contrast, $\alpha$-tocopherol levels showed a 3 fold increase between days 6 and 9, decreased on days 13-16 and increased again in regressive tissue. Thus, at the peak of steroidogenesis at mid-luteal phase $\alpha$-tocopherol levels decreased, but $\beta$-carotene levels increased.

The hydrophobic $\alpha$-tocopherol and $\beta$-carotene are located in the membranes and in the lipid cytoplasmic droplets [40] while the water soluble ascorbate is expected to be in the cytosol and the mitochondrial matrix. Since side chain cleavage of cholesterol is catalyzed by $P 450 \mathrm{scc}$ located in the inner membrane, the lipophilic antioxidants may be more functional in preventing oxidative damage at this first step of steroidogenesis. The decrease of $\alpha$-tocopherol at the peak of steroidogenesis may reflect its consumption by $P 450$ generated oxygen radicals. Thus, this lipophilic antioxidant may "absorb" oxygen radicals first because of its proximity and high reactivity. The repletion of bovine luteal cells with $\beta$-carotene but not with $\alpha$-tocopherol inhibited presumably oxy-radical mediated cross-linking between $P 450 \mathrm{scc}$ and adrenodoxin in $[41,42]$. Thus, it was concluded that the high levels of $\beta$-carotene in corpora lutea may protect against damage due to oxygen free radicals generated in the course of progesterone synthesis $[41,42]$.

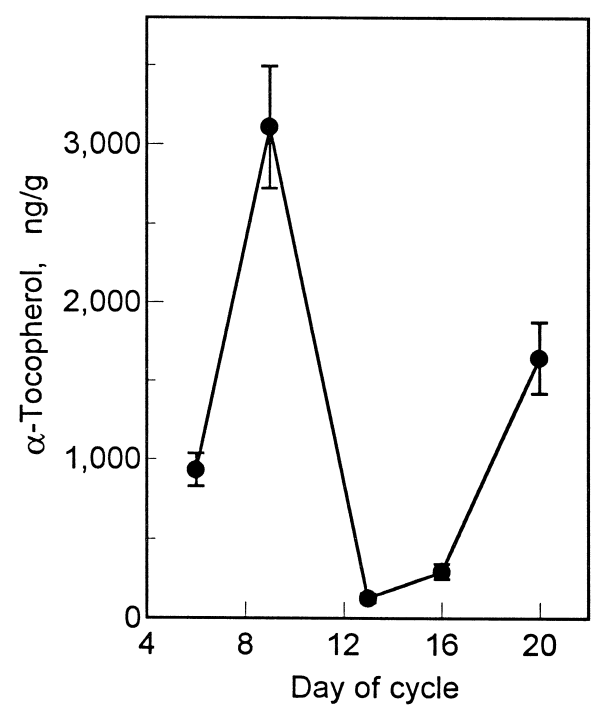

Fig. 6. Concentrations of $\beta$-carotene and $\alpha$-tocopherol in corpus luteum. 
The levels of the antioxidants may also be influenced by reciprocal interactions. During luteal regression, $\beta$-carotene decreased while $\alpha$-tocopherol increased (Fig. 6). Based on similar observations in rats which have a very different estrous cycle, it has been suggested that $\alpha$-tocopherol may be replenished through depletion of ascorbate [38] whereas there is no evidence that $\beta$-carotene may be recycled.

The changes in the levels of the compounds examined may be ascribed to additional functions. $\beta$-carotene in addition to being an antioxidant serves as a precursor of retinol that exerts effects on cellular differentiation and homeostasis through a receptor mediated pathway $[43,44]$. Retinol, retinoic acid and $\beta$-carotene were also reported to stimulate progesterone secretion by porcine luteal cells in vitro [45]. With purified enzymes we observed that $\beta$-carotene stimulated $P 450$ scc activity (unpublished observations). This effect of $\beta$-carotene may be partly mediated by its lipophilic character rather than its antioxidant properties. The depletion of ascorbate during functional luteolysis may at least in part be associated with structural luteolysis as ascorbate plays an essential role in collagen synthesis [46].

Overall, the present study has revealed a complex pattern of regulation and possible function of the antioxidant enzymes and compounds in the bovine corpus luteum. The correlation of the levels of some of these antioxidants with steroidogenesis indicates that antioxidative mechanisms are activated to cope with oxidative stress that is associated with steroid hormone synthesis.

\section{Acknowledgements}

We are grateful to Dr. Fortune Kohen for generous provision of antibodies to progesterone. We also thank Mr. Eli Giresh, and Hagar Sonego for assistance in the synchronization of the cows and the collection of the corpora lutea.

\section{References}

[1] I. Hanukoglu, Steroidogenic enzymes: structure, function, and regulation of expression, J. Steroid Biochem. Mol. Biol. 43 (1992) 779-804.

[2] I. Hanukoglu, Electron transfer proteins of cytochrome $P 450$ systems, Adv. Mol. Cell. Biol. 14 (1996) 29-55.
[3] I. Hanukoglu, R. Rapoport, L. Weiner, D. Sklan, Electron leakage from the mitochondrial NADPH - adrenodoxin reductase-adrenodoxin- $P 450$ scc (cholesterol side chain cleavage) system, Arch. Biochem. Biophys. 305 (1993) 489-498.

[4] R. Rapoport, D. Sklan, I. Hanukoglu, Electron leakage from the adrenal cortex mitochondrial $P 450 \mathrm{scc}$ and $P 450 \mathrm{c} 11$ systems: NADPH and steroid dependence, Arch. Biochem. Biophys. 317 (1995) 412-416.

[5] A.I. Archakov, G.I. Bachmanova, Cytochrome P450 and active oxygen, Taylor \& Francis, Hants, UK, 1990

[6] K. Suzuki, B. Tamaoki, In vitro decrease of lyase activity in rat ovarian cells during incubation: Effect of HCG, Steroids 49 (1987) 341-353.

[7] I. Hanukoglu, Z. Hanukoglu, Stoichiometry of mitochondrial cytochromes $P 450$, adrenodoxin and adrenodoxin reductase in adrenal cortex and corpus luteum: Implications for membrane organization and gene regulation, Eur. J. Biochem. 157 (1986) 27-31.

[8] P.J. Hornsby, Steroid and xenobiotic effects on the adrenal cortex: Mediation by oxidative and other mechanisms, Free Radic. Biol. Med. 6 (1989) 103-115.

[9] P.J. Hornsby, J.F. Crivello, The role of lipid peroxidation and biological antioxidants in the function of adrenal cortex. Part 1: A background review, Mol. Cell. Endocrinol. 30 (1983) 1-20.

[10] R.F. Aten, K.M. Daurate, H.R. Behrman, Regulation of ovarian antioxidant vitamins, reduced glutathione and lipid peroxidation by luteinizing hormone and prostaglandin $\mathrm{F} 2 \alpha$, Biol. Reprod. 46 (1992) 401-407.

[11] B.P. Chew, D.M. Holpuch, J.V. O'Fallon, Vitamin A and $\beta$-carotene in bovine and porcine plasma, liver, corpora lutea, and follicular fluid, J. Dairy Sci. 67 (1984) 1316-1322.

[12] J.C.M. Riley, H.R. Behrman, Oxygen radicals and reactive oxygen species in reproduction, Proc. Soc. Exp. Biol. Med. 198 (1991) 781-791.

[13] T. Endo, R.F. Aten, L. Leykin, H.R. Behrman, Hydrogen peroxide evokes antisteroidogenic and antigonadotropic actions in human granulosa luteal cells, J. Clin. Endocrinol. Metab. 76 (1993) 337-342.

[14] B. Musicki, R.F. Aten, H.R. Behrman, Inhibition of protein synthesis and hormone sensitive steroidogenesis in response to hydrogen peroxide in rat luteal cells, Endocrinology 134 (1994) 588-595.

[15] R.J. Rodgers, M.R. Waterman, E.R. Simpson, Cytochrome $P 450$ scc, $P 45017 \alpha$, adrenodoxin, and reduced nicotinamide adenine dinucleotide phosphate-cytochrome $P 450$ reductase in bovine follicles and corpora lutea. Changes in specific contents during the ovarian cycle, Endocrinology 118 (1986) 1366-1374.

[16] J.J. Ireland, R.L. Murphee, P.B. Coulson, Accuracy in predicting stages of bovine estrous cycle by gross appearance of the corpus luteum, J. Dairy Sci. 63 (1980) 155-160.

[17] A.G. Gornall, C.J. Bardawill, M.M. David, Determination of serum proteins by means of the biuret reaction, J. Biol. Chem. 177 (1949) 751-766. 
[18] J. Bonaventura, W.A. Schroeder, S. Fang, Human erythrocyte catalase: an improved method of isolation and a reevaluation of reported properties, Arch. Biochem. Biophys. 150 (1972) 606-617.

[19] N. Sugino, Y. Nakamura, N. Okuno, M. Ishimato, T. Teyama, H. Kato, Effects of ovarian ischemia-reperfusion on luteal function in pregnant rats, Biol. Reprod. 49 (1993) 354-358.

[20] L.W. Oberly, D.R. Spitz, Nitroblue tetrazolium, CRC Handbook of methods for oxygen radical research, 1989, pp. $217-220$

[21] C. Beauchamp, I. Fridovich, Superoxide dismutase: Improved assays and an assay applicable to acrylamide gels, Anal. Biochem. 44 (1971) 276-287.

[22] I. Hanukoglu, Elimination of non-specific binding in Western blots from non-reducing gels, J. Biochem. Biophys. Methods. 21 (1990) 65-68.

[23] I. Hanukoglu, R. Feuchtwanger, A. Hanukoglu, Mechanism of ACTH and cAMP induction of mitochondrial cytochrome P450 system enzymes in adrenal cortex cells, J. Biol. Chem. 265 (1990) 20602-20608.

[24] I. Hanukoglu, B.S. Suh, S. Himmelhoch, A. Amsterdam, Induction and mitochondrial localization of cytochrome $P 450$ scc system enzymes in normal and transformed ovarian granulosa cells, J. Cell Biol. 111 (1990) 1373-1382.

[25] R.L. Searcy, L.M. Bergquist, A new color reaction for the quantitation of serum cholesterol, Clin. Chim. Acta 5 (1960) 192-199.

[26] F. Kohen, S. Bauminger, H.R. Lindner, Preparation of antigenic steroid-protein conjugate in Steroid Immunoassay, in: E.H.D. Cameron, S.G. Hillier, K. Griffiths (Eds), Steroid Immunoassay, Alpha Omega publishing, Cardiff, Wales, 1975, pp. 11-31

[27] D. Sklan, M. Kaim, U. Moallam, Y. Folman, Effect of dietary calcium-soaps on milk yield, body weight, reproductive hormones, and fertility in first parity and older cows, J. Dairy Sci. 77 (1994) 1652-1660.

[28] L.F. Liebes, S. Kuo, R. Krigel, E. Pelle, E. Silber, Identification and quantitation of ascorbic acid in extracts of human lymphocytes by high-performance liquid chromatography, Anal. Biochem. 118 (1981) 53-57.

[29] R.R. Howard, T. Peterson, P.R. Kastl, High-performance liquid chromatographic determination of ascorbic acid in human tears, J. Chromatogr. 414 (1987) 434-439.

[30] N. Vaisman, B.M. Mogilner, D. Sklan, Vitamin A and E content of preterm and term milk, Nutr. Res. 5 (1985) 931-935.

[31] D. Schams, E. Schallenberger, B. Hoffmann, H. Karg, The oestrus cycle of the cow: hormonal parameters and time relationships concerning oestrus, ovulation, and electrical resistance of the vaginal mucus, Acta Endocrinol. 86 (1977) 180-192.

[32] M. Laloraya, K.G. Pradeep, M.M. Laloraya, Changes in the levels of superoxide anion radical and superoxide dismutase during the estrous cycle of rattus norvegicus and induction of superoxide dismutase in rat ovary by lutropin, Biochem. Biophys. Res. Commun. 157 (1988) 146-153.

[33] N. Sugino, Y. Nakamura, O. Takeda, M. Ishimatsu, H. Kato, Changes in activities of superoxide dismutase and lipid peroxide in corpus luteum during pregnancy in rats, J. Reprod. Fert. 97 (1993) 347-351.

[34] S.J. Hesla, T. Miyazaki, L.M. Dasko, E.E. Wallach, A.M. Dhamarajan, Superoxide dismutase activity, lipid peroxide production and corpus luteum steroidogenesis during natural luteolysis and regression induced by oestradiol deprivation of the ovary in pseudopregnant rabbits, J. Reprod. Fert. 95 (1992) 915-924

[35] E. Gatzuli, R.F. Aten, H.R. Behrman, Inhibition of gonadotropin action and progesterone synthesis by xanthine oxidase in rat luteal cells, Endocrinology 128 (1991) 22532258.

[36] X. Wu, K. Yao, J.C. Carlson, Plasma membrane changes in the rat corpus luteum induced by oxygen radical generation, Endocrinology 133 (1993) 491-495.

[37] X.M. Wu, M. Swada, J.C. Carlson, Stimulation of phospholipase $\mathrm{A}_{2}$ by xanthine oxidase in the rat corpus luteum, Biol. Reprod. 47 (1992) 1053-1058.

[38] R.F. Aten, K.M. Daurate, H.R. Behrman, Regulation of ovarian antioxidant vitamins, reduced glutathione and lipid peroxidation by luteinizing hormone and prostaglandin $\mathrm{F} 2 \alpha$, Biol. Reprod. 46 (1992) 401-407.

[39] J.C.M. Riley, H.R. Behrman, In vivo generation of hydrogen peroxide in the rat corpus luteum during luteolysis, Endocrinology 128 (1991) 1749-1753.

[40] J.V. O'Fallon, B.P. Chew, The subcellular distribution of $\beta$-carotene in bovine corpus luteum, Proc. Soc. Exp. Biol. Med. 177 (1984) 406-411.

[41] F.M. Young, W.B. Luderer, R.J. Rodgers, The antioxidant $\beta$-carotene prevents covalent cross-linking between cholesterol side-chain cleavage cytochrome $P 450$ and its electron donor, adrenodoxin, in bovine luteal cells, Mol. Cell. Endocrinol. 109 (1995) 113-118.

[42] R.J. Rodgers, T.C. Lavranos, H.F. Rodgers, F.M. Young, C.A. Vella, The physiology of the ovary: maturation of ovarian granulosa cells and a novel role for antioxidants in the corpus luteum, J. Steroid Biochem. Mol. Biol. 43 (1995) 241-246.

[43] D. Sklan, $\beta$-Carotene cleavage activity in bovine corpus luteum, Int. J. Vitam. Nutr. Res. 53 (1983) 23-26.

[44] M. Leid, P. Kastner, P. Chambon, Multiplicity generates diversity in the retinoic acid signalling pathways, Trends Biochem. Sci. 17 (1992) 427-433.

[45] F. Talavera, B.P. Chew, Comparative role of retinol, retinoic acid and $\beta$-carotene on progesterone secretion by pig corpus luteum in vitro, J. Reprod. Fert. 82 (1988) 611-615.

[46] T. Endo, R.F. Aten, F. Wang, H.R. Behrman, Coordinate induction and activation of metalloproteinase and ascorbate depletion in structural luteolysis, Endocrinology 133 (1993) 690-698. 